\title{
Satellite tracking reveals unusual diving characteristics for a marine reptile, the olive ridley turtle Lepidochelys olivacea
}

\author{
Clive R. McMahon ${ }^{1,2}$, Corey J. A. Bradshaw ${ }^{1,2, *}{ }^{\text {, Graeme C. Hays }}{ }^{1}$ \\ ${ }^{1}$ Department of Biological Sciences, Institute of Environmental Sustainability, University of Wales Swansea, Singleton Park, \\ Swansea SA2 8PP, UK \\ ${ }^{2}$ School for Environmental Research, Institute of Advanced Studies, Charles Darwin University, Darwin, \\ Northern Territory 0909, Australia
}

\begin{abstract}
The movements, diving behaviour and thermal environment occupied by 4 adult female olive ridley turtles Lepidochelys olivacea in northern Australia were determined through satellite telemetry. Patterns of behaviour recorded were rather unusual compared to other sea turtles in that dives were mainly deep, largely benthic and exceptionally long ( $>2 \mathrm{~h}$ ) in some cases, characteristics typical of over-wintering turtles in colder environments. One individual occupied shallow coastal foraging zones, while the others foraged far from land (probably on the seabed) in relatively deep water $(>100 \mathrm{~m})$. Individuals performed long dives (frequently $>100 \mathrm{~min}$ ), but from the short post-dive intervals we suggest that these dives were mainly aerobic. Maximum dive depth recorded was $200 \pm 20 \mathrm{~m}$ (mean maximum depths ranged from 20.1 to $46.7 \mathrm{~m}$ across individuals; $n=17328$ dives in total; depths $\geq 3 \mathrm{~m}$ were considered 'dives') and the maximum duration was $200 \pm 20$ min (mean durations ranged from 24.5 to $48.0 \mathrm{~min}$ across individuals). Temperature profiles indicate that turtles experienced temperatures ranging from 23 to $29^{\circ} \mathrm{C}$ at the surface, with the lowest temperature recorded $\left(18.7^{\circ} \mathrm{C}\right)$ at a depth of $98 \mathrm{~m}$. Only $6.9 \%$ of the dives were in water $<20^{\circ} \mathrm{C}$. From time-allocation at depth (TAD) scores, we demonstrated that many dives reaching the known or inferred sea bottom were U-shaped, but there was no apparent diel signal in dive depth. This suggests that many benthic dives were not associated exclusively with resting behaviour and likely had a foraging component as well. The ability to perform long benthic dives allows this species to exploit deeper benthic environments in addition to the shallow coastal areas more generally occupied by adult hard-shelled sea turtles (e.g. green and hawksbill turtles). Deep benthic dives also occur in certain marine mammals (e.g. narwhals) and sea birds (e.g. rockhopper penguins) and therefore seem to be a general foraging strategy exploited by animals that can perform long dives.
\end{abstract}

KEY WORDS: Aerobic metabolism - Benthic diving · Foraging strategy · Habitat selection · Movement $\cdot$ Northern Australia $\cdot$ Satellite-relayed data loggers · Temperature profiles

\section{INTRODUCTION}

Phenotypic plasticity, a characteristic occurring in a wide variety of taxa (Tollian \& Harvell 1999), allows an organism to shift its response to different environmental conditions (Bradshaw 1965) via modifications in morphology, physiology and behaviour (Gabriel et al. 2005). As such, species with generalist diets, variable foraging behaviours and many reproductive stra- tegies tend to be buffered from catastrophic environmental shifts that put specialist species at a higher risk of extinction when population sizes are low (Pimm 1991, McKinney 1997, Kotze \& O'Hara 2003). In the marine environment, plasticity in foraging behaviour and diet has been demonstrated for many different higher vertebrate taxa including seabirds (Votier et al. 2004), marine mammals (Thompson et al. 1997, Harcourt et al. 2002) and some fish species 
(Ellis et al. 1996, Garrison \& Link 2000, Bellwood et al. 2006).

Many species of marine turtles, on the other hand, are thought to have rather specialist dietary requirements and consequently, relatively predictable foraging strategies; although some species occasionally undergo pronounced ontogenetic niche shifts (Bjorndal 1997, Salmon et al. 2004, Seaborn et al. 2005). This may be a particularly important aspect of their life history and may help to explain their susceptibility to human activities (many species are Red-Listed with the International Union for Conservation of Nature and Natural Resources (IUCN), www.iucnredlist.org), because the over-exploitation of specific marine habitats on which foraging turtles depend may reduce carrrying capacity. For example, adult hawksbill turtles Eretmochelys imbricata rely heavily on sponges within shallow coral reef systems (Meylan 1988, Leon \& Bjorndal 2002), adult green turtles Chelonia mydas are largely herbivorous and feed mainly on marine algae and seagrasses (Lopez-Mendilaharsu et al. 2005), leatherback turtles Dermochelys coriacea feed almost exclusively on pelagic gelatinous invertebrates (e.g. scypozoan jellyfish and pyrosomes) (Holland et al. 1990, Salmon et al. 2004) and Kemp's ridley turtles Lepidochelys kempii have been found to eat mainly crustaceans (Burke et al. 1994, Seney \& Musick 2005).

Two other species of hard-shelled marine turtle seem to have more plastic foraging behaviour and diets. Loggerhead turtles Caretta caretta have a rather diversified diet including soft-bodied benthic invertebrates, molluscs, crustaceans and fish (Plotkin et al. 1993, Godley et al. 1997, Tomas et al. 2001), and olive ridley turtles Lepidochelys olivacea are thought to be much less of a foraging specialist given their deep-diving behaviour (to $300 \mathrm{~m}$ ) (Landis 1965) and long-distance movement patterns relative to other marine turtle species (Plotkin et al. 1995, Plotkin 1998, Luschi et al. 2003, Plotkin 2003, Polovina et al. 2003, Polovina et al. 2004). Indeed, the available literature suggests that olive ridley turtle diet is highly variable among regions (reviewed in Bjorndal 1997). However, there are few contemporaneous collections of the movement and detailed diving behaviour data needed for a more complete interpretation of olive ridley turtle foraging strategies.

The advent in recent years of satellite-relayed data loggers (SRDLs) has provided a means to overcome the difficulties in obtaining detailed diving behaviour and relatively precise location data in the study of the foraging behaviour of wide-ranging marine vertebrates (Fedak et al. 2002, Hays et al. 2004b). These sophisticated instruments not only provide accurate locations in real time, they also give information describing the environmental conditions in which the animals forage
(McMahon et al. 2005) that is useful for quantifying habitat selection and range extents. This is especially important for species that range widely and spend the majority of their life cycles submerged (Myers et al. 2006). Thus, to address the gaps in our understanding of olive ridley turtle behaviour and to examine whether observations of this species' juvenile movement patterns elsewhere (Polovina et al. 2003, Polovina et al. 2004) imply a broad foraging niche for adults, we deployed SRDLs on 4 female turtles in northern Australia during the post-nesting migration. In addition to the important knowledge gap this research addresses, it also provides data essential for the effective management of olive ridley turtles in Australia. The predicted wide range of this species suggests a potentially high susceptibility to human fishing activities (e.g. Polovina et al. 2004) from several nations bordering the Arafura and Timor Seas, and it has fundamental social and practical management implications for different aboriginal groups attempting to manage this important seasonal food resource (Kennett et al. 2004).

\section{MATERIALS AND METHODS}

Satellite-relayed data loggers (SRDLs, manufactured by the Sea Mammal Research Unit [SMRU], University of St. Andrews, United Kingdom, www.smru. st-and. ac.uk) were attached to the carapaces of 4 female olive ridley turtles nesting in the Wessel Islands of Arnhem Land in the Northern Territory of Australia (Graham Island: $11^{\circ} 45^{\prime} \mathrm{S}, 135^{\circ} 57^{\prime} \mathrm{E}$ and Wunpirri Island: $11^{\circ} 36^{\prime} \mathrm{S}, 136^{\circ} 05^{\prime} \mathrm{E}$ ) using quick-setting epoxy glue. Standard curved carapace length (SCCL) was measured for all individuals prior to SRDL-unit attachment, where SCCL is the distance from the anterior point at midline (nuchal scute) to the posterior tip of the supracaudal (Shanker et al. 2004). Weights were not measured, but we estimated mass from a SCCLweight relationship derived from olive ridley turtles captured during a World Wildlife Fund for Nature (WWF) Australia program (5 turtles, morphometric measurements available from http://wwf. org.au/ ourwork/oceans/oliveridleytrackingbios/).

The SRDL function and attachment procedures are summarized in detail elsewhere (Hochscheid et al. 2005, McMahon et al. 2005). However, we modified previous procedures by mounting the SRDLs prior to attachment onto an epoxy wedge (base $=125 \mathrm{~mm}$, width $=70 \mathrm{~mm}$, height $=32 \mathrm{~mm}$, hypotenuse $=92 \mathrm{~mm}$, slope $=20^{\circ}$ ) with glue so that the antenna would point perpendicular to the sea surface to improve communication with the satellites upon the turtle surfacing (SMRU SRDLs are constructed so that the antenna points forward at an angle of approximately $20^{\circ}$ ). We 
observed that the long axis of olive ridley turtles swimming at the surface was $\sim 0^{\circ}$, so the SRDL-wedge configuration appeared to maximize the occurrence of a vertical antenna position when the animal first surfaces to breathe.

Argos location data were summarized such that average daily positions were interpolated from the scatter of points available for each day. For this analysis, only high-quality Argos locations of quality class A, 1, 2 and 3 were used (see Hays et al. 2001 for accuracy estimates for each class). We first interpolated these high-quality locations using custom R code (R Development Core Team 2004) developed by D. Pinaud (Pinaud \& Weimerskirch 2005) with an interpolation distance set to $0.2 \mathrm{~km}$. Using this interpolated set, the mean latitude and longitude were then calculated for each day of the trip.

In addition to Argos location data, SRDLs provided 4 measures of diving behaviour: (1) long-form dive profiles with information on dive shape (Myers et al. 2006); (2) short-form dives, recording information for single dives that only included surface duration, dive duration, time of end of dive and maximum dive depth (Hochscheid et al. 2005); (3) 24-h summary statistics of diving events based on all the data recorded by the SRDL (these statistics include mean \pm SD dive duration, maximum dive duration, mean \pm SD depth, maximum depth, number of dives and the proportion of time spent either diving or at the surface) (Hochscheid et al. 2005); and (4) temperature-depth profiles of the deepest dive over a minimum time interval of $2 \mathrm{~h}$. Due to the limited bandwidth available with the Argos system, depth values, while measured accurately, were not relayed with detailed precision. Near the surface (to $10 \mathrm{~m}$ ), depth was relayed to the nearest $1 \mathrm{~m}$, but this precision decreased with depth such that at $140 \mathrm{~m}$, depth was relayed to the nearest $20 \mathrm{~m}$. Similarly, for short dives (0 to $10 \mathrm{~min}$ ), dive duration was relayed to the nearest min, but precision decreased thereafter so that a dive of 180 min duration was relayed to the nearest $20 \mathrm{~min}$. To examine diel patterns in diving behaviour, we calculated the local solar mid-time (LST) for each dive as LST $=$ GMT + (longitude/15) (Bradshaw et al. 2002) and examined patterns in mean dive duration, maximum depth and the proportion of time spent diving per LST hourly bin.

Depth and temperature were measured every $4 \mathrm{~s}$, then key points of inflexion of the dive profile were determined at the end of a dive and relayed via the Argos system (Fedak et al. 2002). For long-form dives, up to 5 points of inflexion, dive duration and the end time of the dive were relayed. For temperature profiles, 12 points of inflexion were determined in a manner consistent with the processing of expendible bathythermograph (XBT) data. See Myers et al. (2006) for a full description of depth profiles and McMahon et al. (2005) for a description of the how temperature profiles are measured by SRDLs. SMRU SRDLs have a $2000 \mathrm{~m}$ depth transducer with a $0.5 \mathrm{~m}$ resolution, and water temperature is accurate to $0.1^{\circ} \mathrm{C}$ (www.smru.stand.ac.uk). The depth threshold for diving was $\geq 3 \mathrm{~m}$ (i.e. all dives $<3 \mathrm{~m}$ were considered at-surface noise). Sea surface temperatures (SST) were taken as those temperatures recorded in the uppermost depth bin.

To examine whether turtles were diving to the ocean floor, we determined the ocean depth for a particular dive location using the General Bathymetric Chart of the Oceans (GEBCO) (IOC/IHO/BODC 2003) and then established whether the maximum depth for a particular dive was within $10 \%$ of the depth described in the GEBCO atlas. However, bathymetric data were not always available for particular locations, so we consulted a hydrographic chart (Royal Admirality 2003) to determine the depth of the sea floor. In some cases, the maximum-recorded dive depths exceeded the reported bathymetric maximum, so here we assumed the sea floor depth was equivalent to the maximum depth of the dive in question.

Long-form dive profiles have a variety of 'shapes' that can be quantified using the Time-Allocation at Depth (TAD) index developed for SRDL-collected data (Fedak et al. 2001). Our goal was to estimate the proportion of the bottom-attaining dives (as defined above) that followed the classic U-shape typically associated with benthic activities. The TAD index uses relevant data from dive profiles to highlight where in the dive an individual forager centres its activity with respect to depth (Takahashi et al. 2003):

$$
\mathrm{TAD}=\frac{\sum_{i}^{n} \frac{\left(d_{i+1}+d_{i}\right)\left(t_{i+1}-t_{i}\right)}{2}-\left(\frac{d_{\max }^{2}}{S}\right)}{\left(d_{\max } \times\left(t_{n}-t_{1}\right)\right)-\left(\frac{2 d_{\max }^{2}}{S}\right)}
$$

where $d_{i}=$ an individual depth reading for depth reading $i$ in a dive, $t_{i}=$ the time of depth reading $i, d_{\max }=$ the maximum dive depth and $S=$ a predefined average rate of change of depth. For our analyses, $S$ was set to $1.4 \mathrm{~m} \mathrm{~s}^{-1}$. This ensured that the TAD index would vary between 0 and 1 , with values near 0.5 corresponding to more V-shaped dives and values near 1.0 indicating more U-shaped (benthic) dives. We also tested the sensitivity of the TAD to variation in $S_{\text {; }}$ reducing $S$ to $1.0 \mathrm{~m} \mathrm{~s}^{-1}(-28 \%)$ changed the median TAD of Turtle A by only $0.4 \%$ (from 0.8679 to 0.8714 ), and increasing $S$ to $2.0 \mathrm{~m} \mathrm{~s}^{-1}(+43 \%)$ increased the TAD by only $0.3 \%$.

The relationships between post-dive surface intervals and dive duration were examined using linear regression, with the strength of evidence for a relationship assessed using the information-theoretic evidence ratio $(E R)$. This is equal to the Akaike's Information 
Criterion (Akaike 1973) corrected for sample size $\left(\mathrm{AIC}_{\mathrm{c} i}\right.$ Burnham \& Anderson 2002) weight of the full model $\div \mathrm{AIC}_{\mathrm{C}}$ weight of the intercept model, and the least-squares $r^{2}$ value to quantify structural goodnessof-fit.

Diel patterns in dive duration, maximum dive depth and the proportion of time spent diving were investigated using linear mixed-effects models (LME) using a reduced maximum-likelihood (REML) structure (Pinheiro \& Bates 2000). Models considered only the hourof-day covariate for each response model. Although this structure captures the main diel trends, it ignores any trends between days given the linear covariate of time set as hour of the day. Due to the autocorrelation inherent in time series of these behavioural indices, we assessed the first-order autocorrelation coefficients for each response variable and averaged these over all individuals. These mean coefficients were then set in the LME model structure (mean autocorrelation coefficients were $0.70,0.54$ and 0.41 for duration, maximum depth and proportion of time spent diving, respectively), with the random effect set to 'individual' (Pinheiro \& Bates 2000). To correct for non-Gaussian distributions of the response variables, we log-transformed duration and maximum depth, and took the complementary log-log of the proportion of time spent diving. Model support was assessed using an informationtheoretic index (AIC and ER) as outlined above, and structural goodness-of-fit was determined from the percent of the deviance explained (\%DE) by the single-term models. All analyses were done using the $\mathrm{R}$ software package (R Development Core Team 2004), and all values are shown as means $\pm 1 \mathrm{SD}$.

\section{RESULTS}

\section{Morphometrics and data retrieval}

The 4 female olive ridley turtles fitted with SRDLs had a SCCL of 68.5, 68.0, 69.6 and $68.8 \mathrm{~cm}$ (Turtles A-D, respectively). The SCCL-weight relationship from the WWF data was $\hat{W}=-75.0623+1.5715 \times$ SCCL
( $\hat{W}=$ estimated weight, $\left.\mathrm{r}^{2}=0.97, F_{1,3}=125, \mathrm{p}=0.002\right)$. This equation predicted weights of $32.6,31.8,34.3$ and $33.1 \mathrm{~kg}$ for Turtles A-D, respectively. SRDLs provided large volumes of high-quality data (Table 1). We obtained a total of 534 turtle-days of tracking data (mean track duration $=134 \mathrm{~d})$, giving 3043 locations ranging from Class B to 3 (Table 1). Of those locations, $630(18.7 \%)$ were of highest quality (Location Classes 1 to 3). Conductivity data (not shown) suggested the units ceased transmission due to biofouling rather than battery failure or detachment.

\section{Movement patterns}

The individuals tracked went in 3 general directions after leaving the nesting beaches (Fig. 1): Turtles A and B spent approximately 26 and $18 \mathrm{~d}$, respectively, in the vicinity of the island where they nested (possibly nesting again during this period) before departing the region (Fig. 1A,B). Turtles $\mathrm{C}$ and $\mathrm{D}$ left the nesting area immediately on northward and westward migrations, respectively (Fig. 1C,D). The duration of migrations to foraging areas ranged from 15 to $36 \mathrm{~d}$ (Fig. 1); 'foraging areas' were defined as the approximate regions where directed migrations ceased and were replaced by more convoluted and overlapping tracks (Fig. 1). Turtles A and B settled in single foraging areas, but Turtles C and $\mathrm{D}$ had 2 and 3 main foraging areas, respectively (Fig. 1A-D).

\section{Dive patterns}

SRDLs collected a total of 3501 long-form dive profiles, 13827 short-form and 496 24-h summaries (Table 1). We used information from the 24-h summaries to estimate the proportion of dives relayed for each turtle. Overall the number of dives relayed ranged from 69.6 to $96.8 \%$ of the total possible number of dives (Table 2), and of those relayed, the longform represented between 15.3 and $22.7 \%$ of dives (Tables 1 \& 2). Taking into consideration the decreas-

Table 1. Lepidochelys olivacea. Summary information from 4 satellite-relayed data logger (SRDL) deployments on post-nesting olive ridley turtles (A-D) from the Wessell Islands, Northern Territory, Australia. Dates given as dd/mm/yy

\begin{tabular}{|c|c|c|c|c|c|c|c|c|c|c|c|}
\hline \multirow{2}{*}{$\begin{array}{l}\text { Turtle } \\
\text { ID }\end{array}$} & \multirow[t]{2}{*}{ Dates } & \multirow{2}{*}{$\begin{array}{l}\text { Days } \\
\text { tracked }\end{array}$} & \multicolumn{6}{|c|}{ Links in each Argos location class } & \multirow{2}{*}{$\begin{array}{l}\text { Long-form } \\
\text { dives }\end{array}$} & \multirow{2}{*}{$\begin{array}{c}\text { Short-form } \\
\text { dives }\end{array}$} & \multirow{2}{*}{$\begin{array}{c}24-\mathrm{h} \\
\text { summaries }\end{array}$} \\
\hline & & & B & A & 0 & 1 & 2 & 3 & & & \\
\hline A & $11 / 05 / 05-10 / 10 / 05$ & 133 & 251 & 143 & 71 & 21 & 23 & 9 & 556 & 3055 & 126 \\
\hline B & $10 / 05 / 05-27 / 07 / 05$ & 78 & 72 & 57 & 128 & 66 & 21 & 11 & 414 & 1590 & 76 \\
\hline $\mathrm{C}$ & 06/05/05-19/10/05 & 167 & 280 & 189 & 375 & 142 & 59 & 13 & 1192 & 4625 & 161 \\
\hline $\mathrm{D}$ & 06/05/05-18/09/05 & 156 & 322 & 223 & 302 & 131 & 101 & 103 & 1339 & 4557 & 133 \\
\hline Total & & 534 & 925 & 612 & 876 & 360 & 204 & 66 & 3501 & 13827 & 496 \\
\hline
\end{tabular}



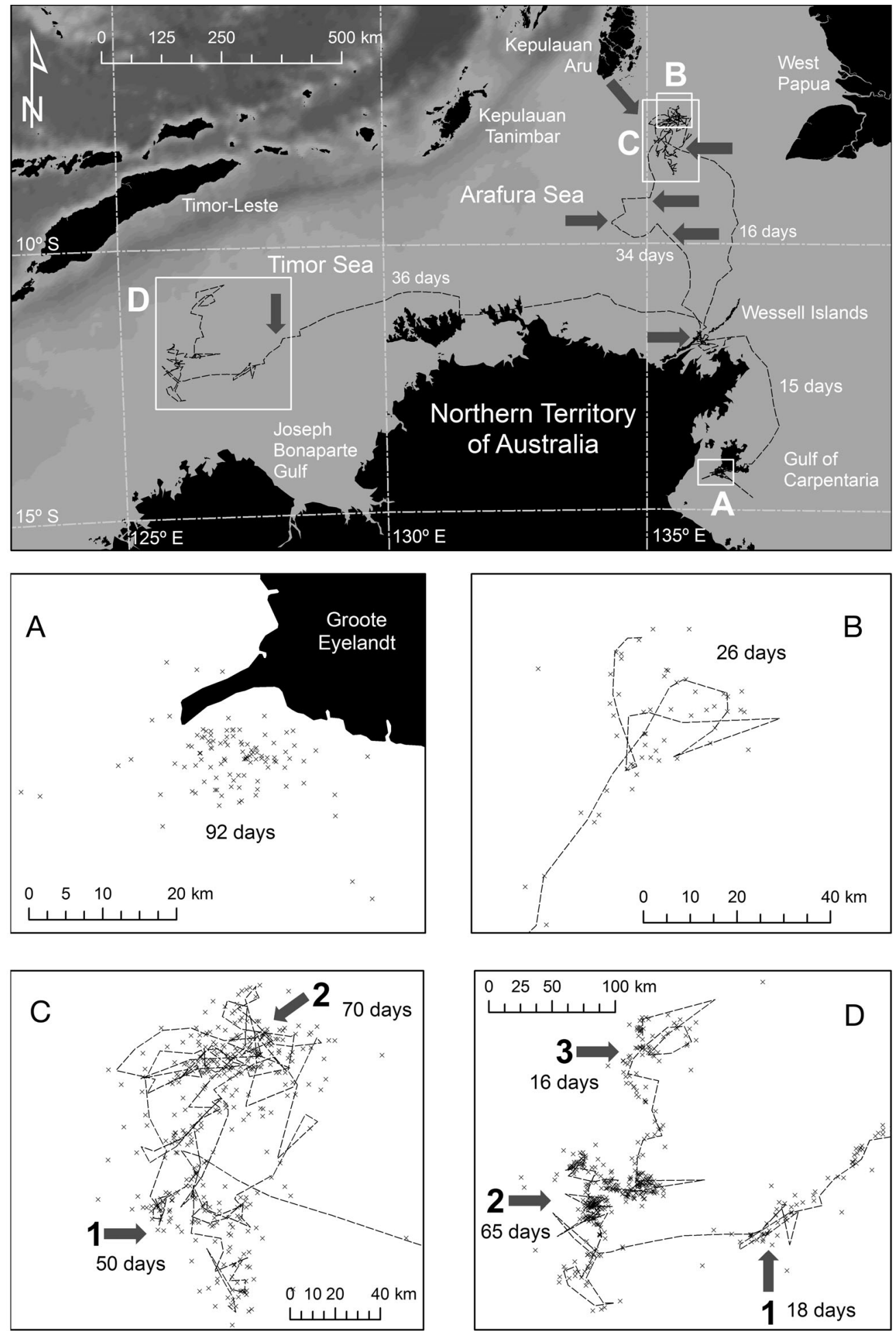

Fig. 1. Lepidochelys olivacea. Movement patterns during post-nesting migration and foraging of 4 olive ridley turtles tracked from the Wessell Islands in the Northern Territory of Australia. Top panel = general distribution of individuals relative to the nesting areas (mean daily interpolated positions and approximate duration of transit pathways and foraging phases in days). Top panel arrows = approximate positions of deepest dives. Grey-scale colour = bathymetry variation. Panels A-D = focal foraging regions for Turtles $\mathrm{A}-\mathrm{D}$, with mean daily interpolated track (Turtles B-D only) and distribution of high-quality (Argos Location Classes A, 1, 2, 3) locations. Arrows in panels C, D = major foraging areas. Days = approximate number of days in each foraging area 
Table 2. Lepidochelys olivacea. Estimated proportion of total dives for Turtles A-D, as determined from the total number of dives and the 24-h summary for each turtle's satellite-relayed data logger (SRDL) record

\begin{tabular}{|lccc|}
\hline $\begin{array}{l}\text { Turtle } \\
\text { ID }\end{array}$ & $\begin{array}{c}\text { Mean } \\
\text { dives d }^{-1}\end{array}$ & Dives relayed & $\begin{array}{c}\text { \% of all } \\
\text { dives relayed }\end{array}$ \\
\hline A & 39.0 & 3611 & 69.6 \\
B & 27.5 & 2004 & 93.4 \\
C & 36.0 & 5817 & 96.8 \\
D & 47.0 & 5896 & 80.4 \\
\hline
\end{tabular}

ing precision of depth and times relayed with the increasing values of these parameters, the maximum dive depth relayed was $200 \pm 20 \mathrm{~m}$ (precision indicates error associated with data compression at this depth range) and the maximum duration was $200 \pm 20 \mathrm{~min}$ $(3.33 \pm 0.33 \mathrm{~h})$. The deepest long-form dive profiles were from Turtle D at $140 \mathrm{~m}$, followed by $120 \mathrm{~m}, 100 \mathrm{~m}$ and $50 \mathrm{~m}$ for Turtles B, C and A, respectively (Fig. 2). An examination of the median maximum dive depth and duration for the 3 phases identified for each track (i.e. pre-transit, transit and foraging area) revealed high variation among phases for each turtle (data not shown). However, there was a suggestion of an increasing maximum depth and duration from the pretransit to the transit phase. There was little difference in these parameters between the transit and foragingarea phases.
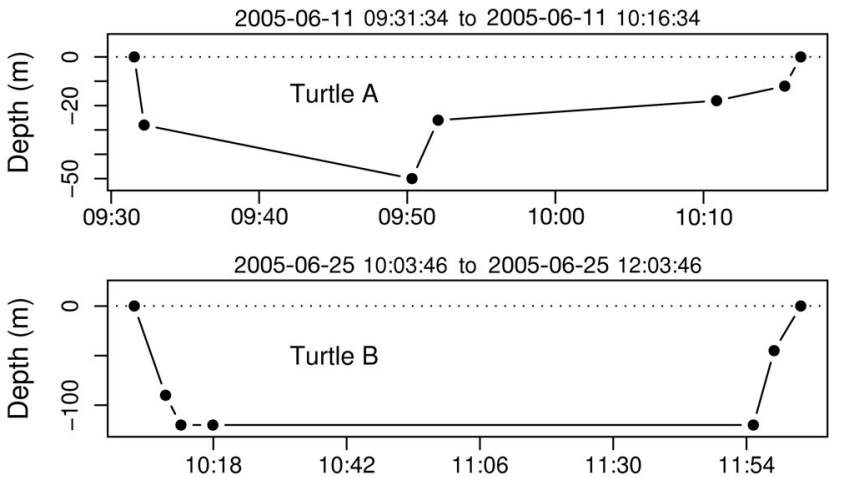

2005-05-25 05:31:26 to $2005-05-25$ 06:36:26

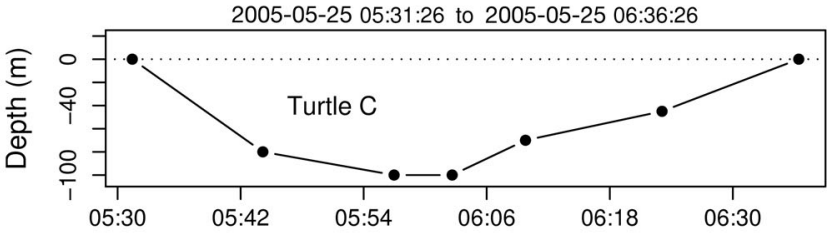

2005-06-09 09:46:30 to 2005-06-09 10:16:30

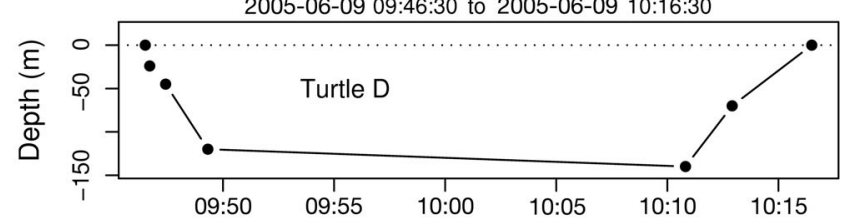

Fig. 2. Lepidochelys olivacea. Examples of 2 long-form dive profiles each from Turtles A-D with maximum depths vs. dates and times
Mean maximum dive depths were similar for Turtles $\mathrm{B}-\mathrm{D}(46.7 \pm 30.2 \mathrm{~m}, 46.0 \pm 21.9 \mathrm{~m}$ and $46.2 \pm 27.6 \mathrm{~m}$, respectively) (Fig. 3), but Turtle A dived considerably shallower $(20.1 \pm 9.4 \mathrm{~m})$, consistent with its travelling and foraging closer to land (Fig. 1). Most dives (66.3\%) were shallower than $50 \mathrm{~m}$, and only $0.4 \%$ were $>100 \mathrm{~m}$, with the 50, 75, 95 and 99 percentiles being 35, 50, 90 and $100 \mathrm{~m}$, respectively. Mean dive durations were more variable, with Turtle B having the longest mean duration (48.0 $\pm 35.3 \mathrm{~min})$, followed by Turtles A, C, and $\mathrm{D}(37.2 \pm 27.5 \mathrm{~min}, 33.7 \pm 17.0 \mathrm{~min}$ and $24.5 \pm 17.2 \mathrm{~min}$, respectively) (Fig. 3). Most dives (66.7\%) were less than $40 \mathrm{~min}$ in duration, and $9.5 \%$ exceeded $60 \mathrm{~min}$, with the 50, 75, 95 and 99 percentiles being 30, 45, 75 and $115 \mathrm{~min}$, respectively. However, frequency histograms of dive duration do not demonstrate the allocation of time within each dive; therefore, we also plotted the proportion of total time spent within each duration bin (Fig. 4) to demonstrate that a large portion of the time was spent in dives of long duration. The relationships between dive duration and maximum depth were considerably different among turtles (Fig. 5). Plots of the mean and quartile ranges of mean duration vs. depth indicated that mean duration increased with depth up to approximately 28, 100, 30 and $50 \mathrm{~m}$ for Turtles A, B, $\mathrm{C}$ and D, respectively (Fig. 5). Fewer dives at depths $>100 \mathrm{~m}$ than at $<100 \mathrm{~m}$ complicates conclusions, but in general, those turtles diving the deepest did not necessarily dive for the longest durations.

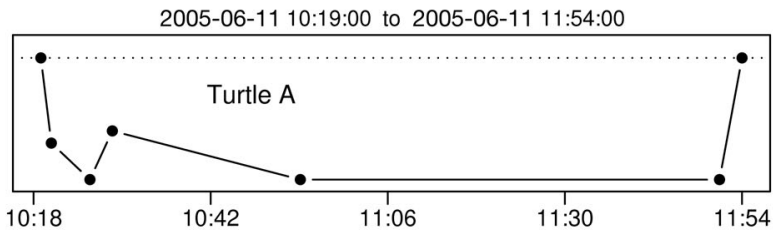

2005-06-27 07:13:30 to 2005-06-27 08:08:30

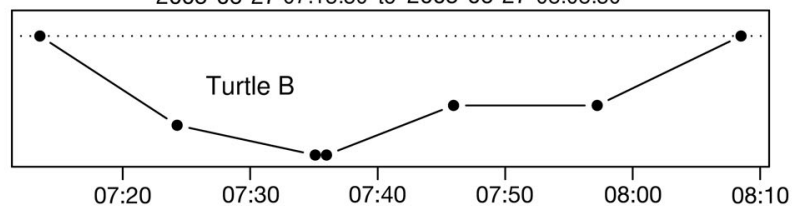

2005-05-25 18:01:00 to 2005-05-25 19:11:00

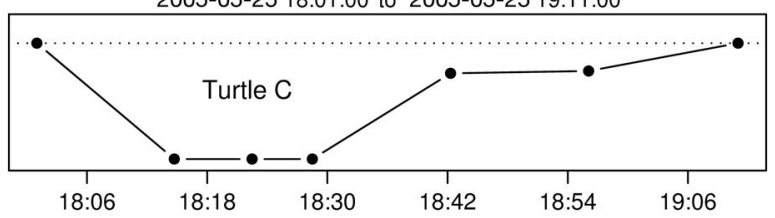

2005-06-08 23:33:34 to 2005-06-08 23:55:34

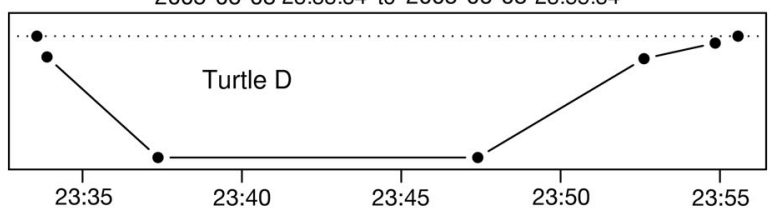




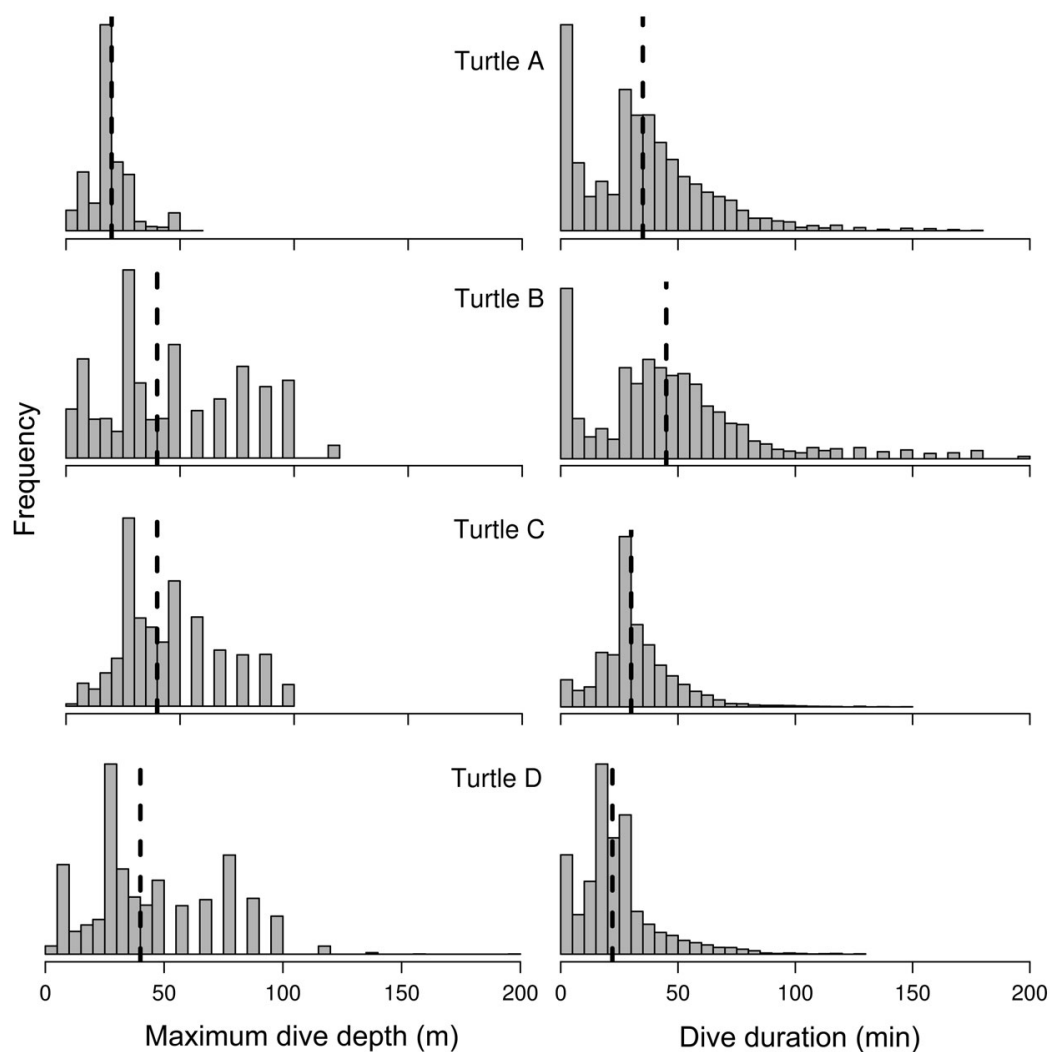

Fig. 3. Lepidochelys olivacea. Maximum dive depth and duration for Turtles A-D. Median values $=$ dashed vertical line; $y$-axis values show relative frequency

After assuming that any dive with a maximum depth within $10 \%$ of the estimated bottom depth had reached the seabed, the majority of dives $(66.0 \%)$ reached the bottom at least once during the dive. There was considerable variation among turtles; for example, Turtle A with the shallowest dives and the most in-shore foraging track (Fig. 1) had the majority of its dives at or
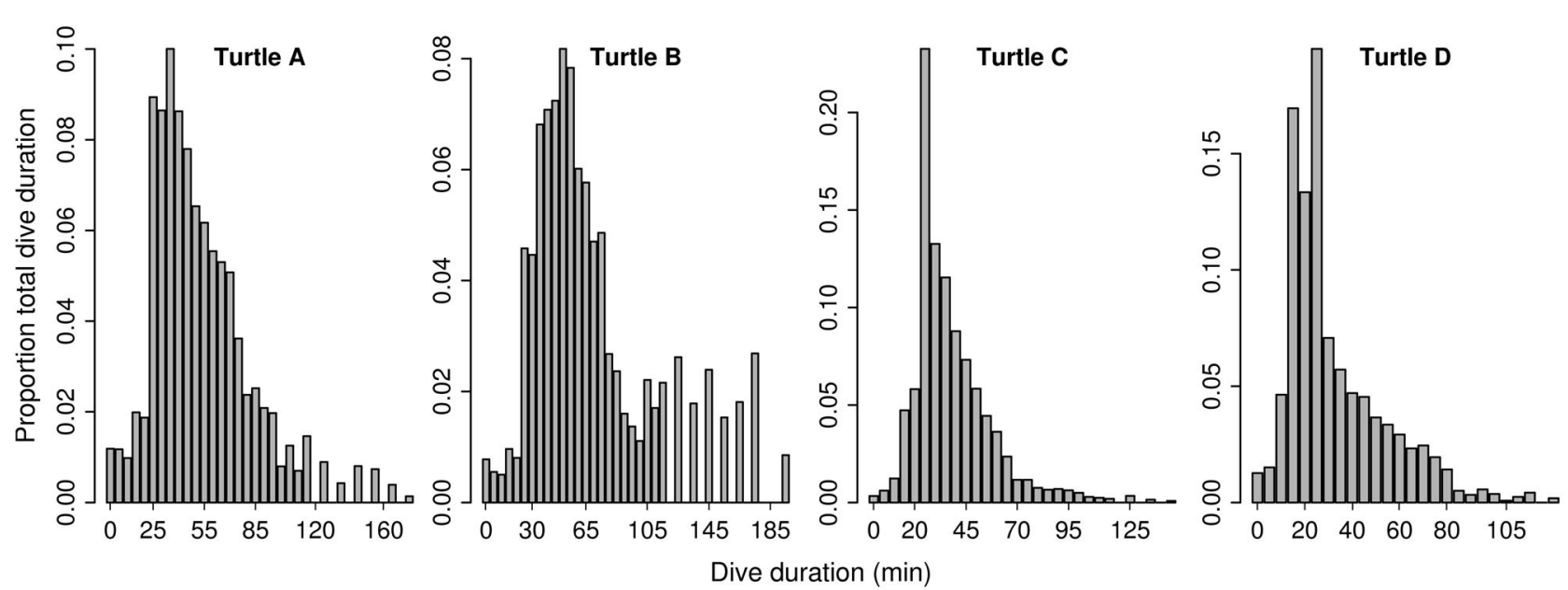

near the bottom (Fig. 6). Turtles C and D had a more oceanic distribution (Fig. 1) and considerably fewer dives reaching the bottom, although the majority of their dives were still considered bottom dives (Fig. 6). Turtle B had a similar foraging distribution to Turtle $\mathrm{C}$, but the former had many more dives to the bottom. To examine if these bottom-reaching dives might relate, at least in part, to benthic foraging (i.e. most of the dive spent at the bottom; 'U-shaped' dive), we examined the distribution of TAD for each turtle. An examination of bottom dives with TAD >0.75 generally demonstrated a bottom phase suggestive of benthic behaviour, and the proportion of bottom dives with a TAD $>0.75$ were $0.62,0.66,0.47$ and 0.43 for Turtles A, B, $\mathrm{C}$ and $\mathrm{D}$, respectively. Of course, the decreasing precision with depth suggests that the true proportion of dives deemed 'benthic' might actually be smaller given that the flat bottom of deep, U-shaped dives may in fact be more variable than suggested by our data.

Diel patterns in diving behaviour demonstrated some interesting trends. Although there were no clear patterns in mean maximum dive depth, there was some suggestion of a peak in mean depths during the later hours of the morning (09:00-10:00 h) and early evening (18:00-20:00 h), especially for Turtles B-D (Fig. 7, toprow left panel). However, the LME models demonstrated little support for an hour-of-day effect on the log of maximum dive depth $(E R<1, \mathrm{DE} \cong 0 \%)$. Mean dive

Fig. 4. Lepidochelys olivacea. Dive duration for Turtles A-D as proportion of the total time within each duration bin. Dive duration bins represent 5 min increments 


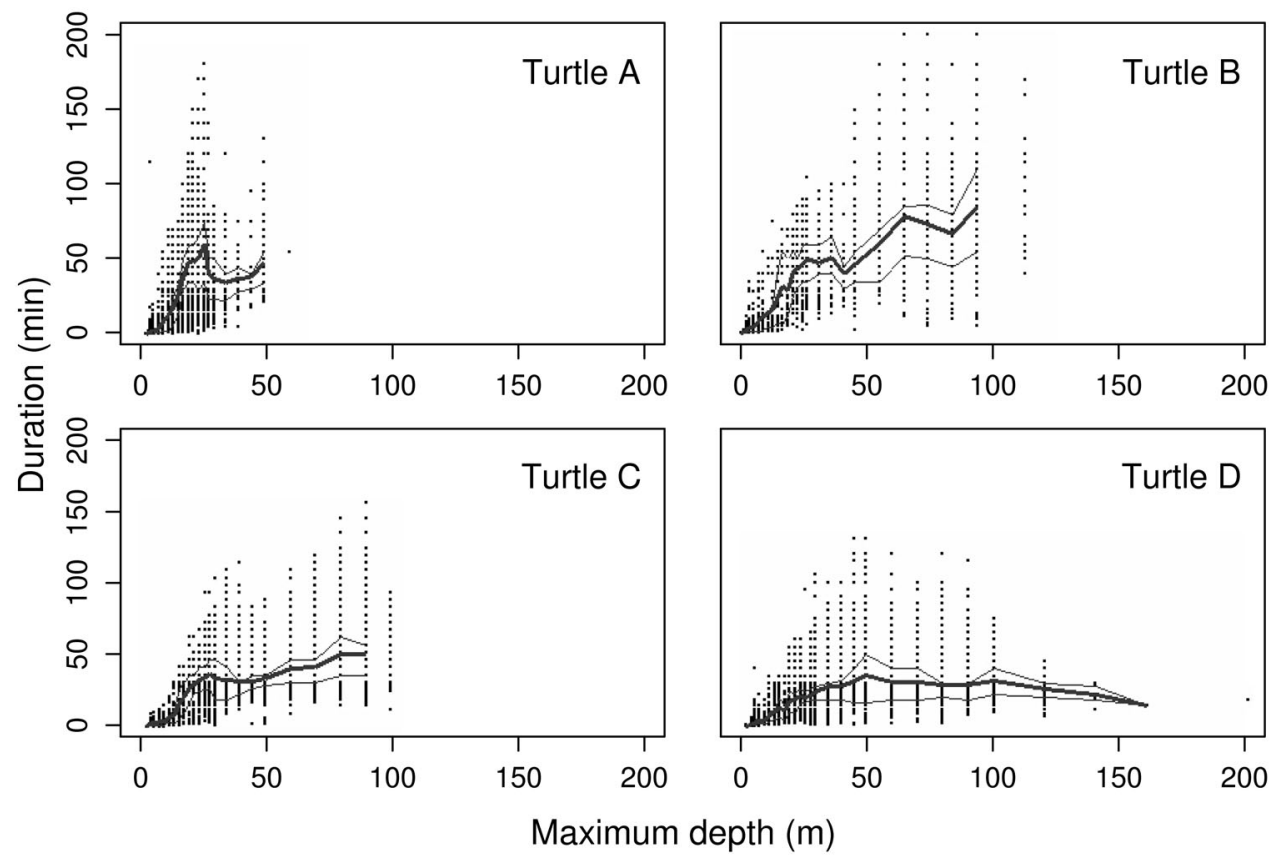

Fig. 5. Lepidochelys olivacea. Relationship between dive duration and maximum depth for Turtles A-D. Solid lines $=$ mean duration per depth bin. Thin lines $=25$ and $75 \%$ quartiles of duration at each incrementing depth bin

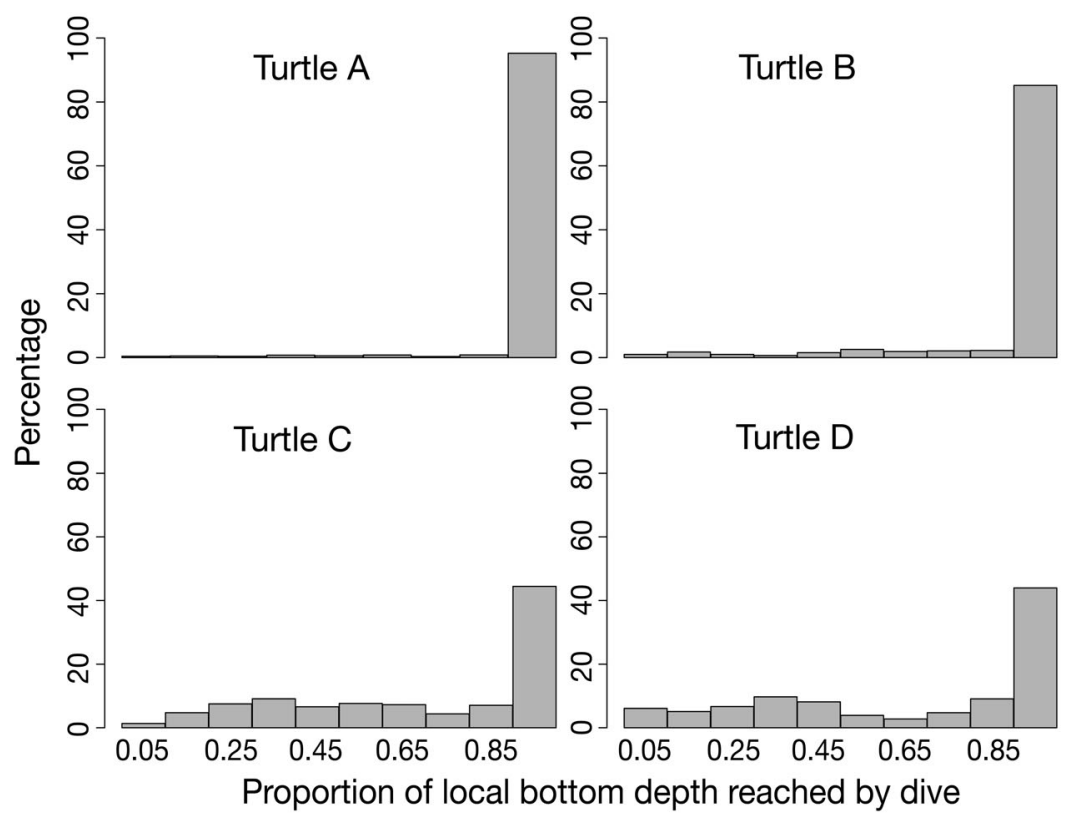

Fig. 6. Lepidochelys olivacea. Percentage of proportion of bottom depth reached by a dive for Turtles A-D

duration showed clear diel patterns with a maximum duration occurring at approximately 04:00 h local time and a minimum duration between 12:00 and 17:00 $\mathrm{h}$ local time (Fig. 7, top-row middle panel). The LME model supported an effect of hour-of-day on dive duration $\left(E R=3.3 \times 10^{13}\right)$; however, the deviance explained was low $(\mathrm{DE}=0.13 \%)$. This was mimicked by a maximum in the proportion of time spent diving (average range $=87.7-94.1 \%$ ) between 03:00 and 05:00 $\mathrm{h}$, and a minimum in this measure between 10:00 and 17:00 h
$(E R=7768, \mathrm{DE}=0.07 \%)($ Fig. 7, top-row right panel). For bottom dives only, the diel patterns in maximum depth, duration and proportion of time spent diving were far more variable, and the patterns appeared to mimic those of all dive types (Fig. 7, bottom-row panels).

The post-dive surface interval and dive duration relationships varied substantially among individuals (Fig. 8). There was little suggestion of a positive relationship for Turtle A $\left(E R=5.0, \mathrm{r}^{2}=\right.$ $0.001)$, but convincing positive relationships for Turtles B and C $(E R=9.0 \times$ $10^{107}$ and $6.9 \times 10^{157}, \mathrm{r}^{2}=0.22$ and 0.12 , respectively). There was perhaps a weak negative relationship for Turtle D $\left(E R=2.1 \times 10^{8}, \mathrm{r}^{2}=0.007\right)$. These differences among individuals are due possibly to the variation in the number of dives of short duration, with the shorterduration dives explaining the negative relationship for Turtle D (Fig. 8).

Turtles A-D experienced SST between 23 and $29^{\circ} \mathrm{C}$ during the course of their records, and median SSTs were similar for all individuals (overlapping 95\% CI) (Fig. 9). However, there were some seasonal differences in daily SST experienced by each turtle. Overall there was a general pattern of cooling toward the end of July, and Turtles B and C experienced similar patterns throughout their records (Fig. 9). Turtle D experienced warmer average SSTs travelling west, and Turtle A encountered cooler temperatures upon heading 

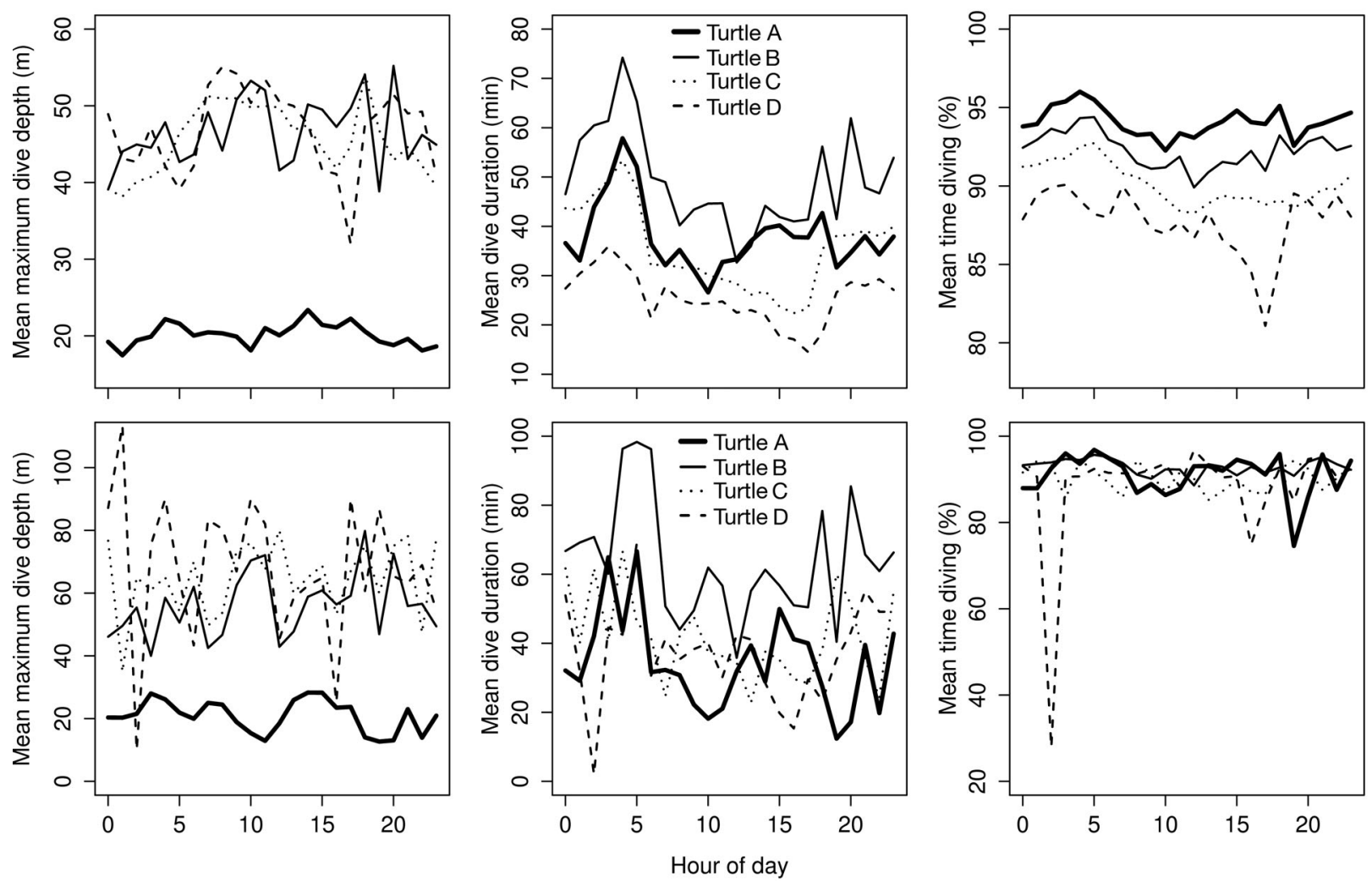

Fig. 7. Lepidochelys olivacea. Top-row panels = diel patterns for all dives with (center panel) mean duration, (left panel) mean maximum dive depth and (right panel) mean percent time diving. Bottom-row panels = diel patterns for bottom dives only. Times in local solar time (LST)

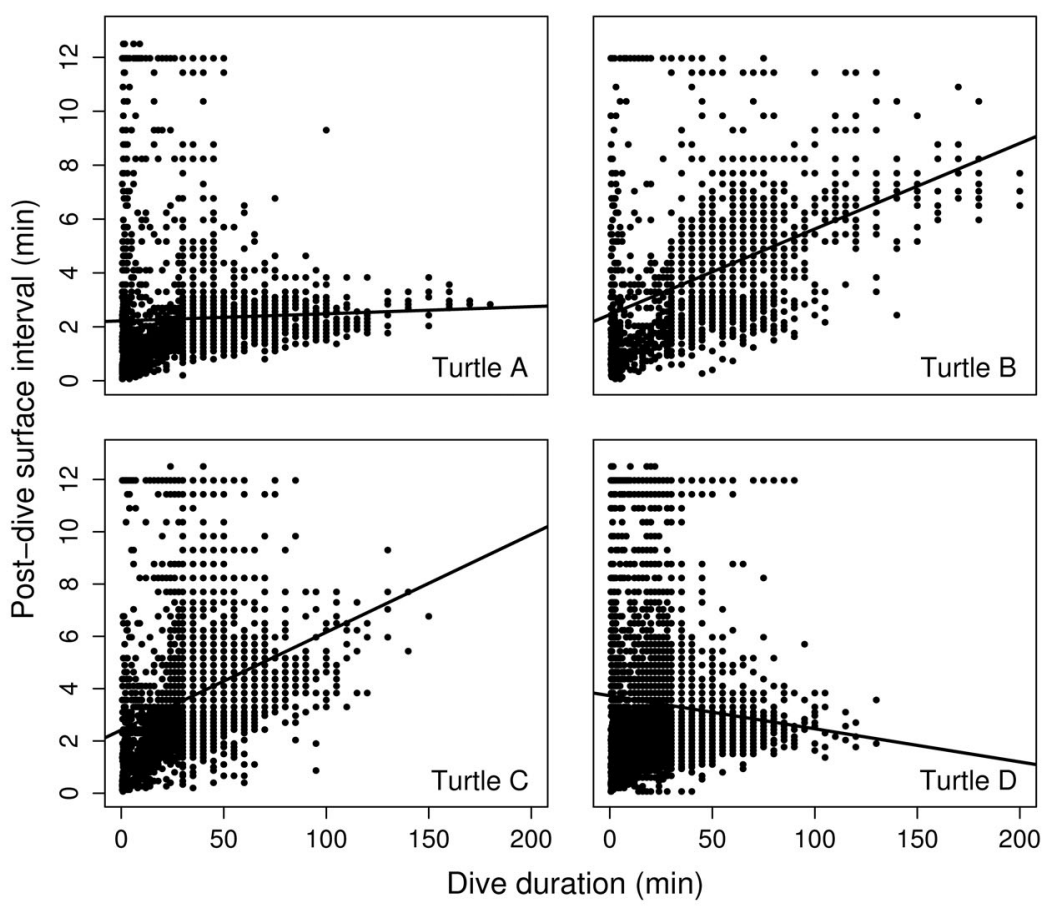

Fig. 8. Lepidochelys olivacea. Relationship between post-dive surface interval and dive duration for Turtles A-D with least-squares linear regression line of best fit for each south into the Gulf of Carpentaria (Figs. 1 \& 9). Examination of the depthtemperature profiles demonstrated that in some instances there was an approximate $9^{\circ} \mathrm{C}$ difference between surface and maximum depth temperatures (Turtle B). In other cases, even deep dives showed remarkably little temperature variation within the water column. The minimum temperature at depth was $18.7^{\circ} \mathrm{C}$ experienced by Turtle $\mathrm{B}$ on 8 June 2005 at a depth of $98 \mathrm{~m}$; however, only $6.9 \%$ of the dives with temperature profiles were in water that was $<20^{\circ} \mathrm{C}$ (Turtles B and C only).

\section{DISCUSSION}

Dives recorded during post-nesting migration and foraging from 4 olive ridley turtles supported the prediction that this species demonstrates high habitat plasticity by using a broad range of habitats (inshore coastal and oceanic) 


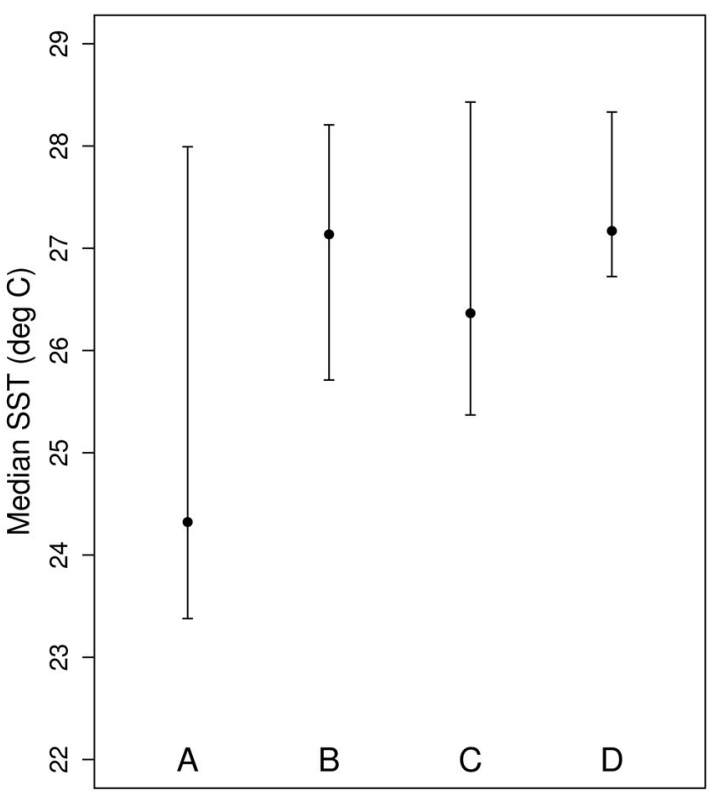

Turtle

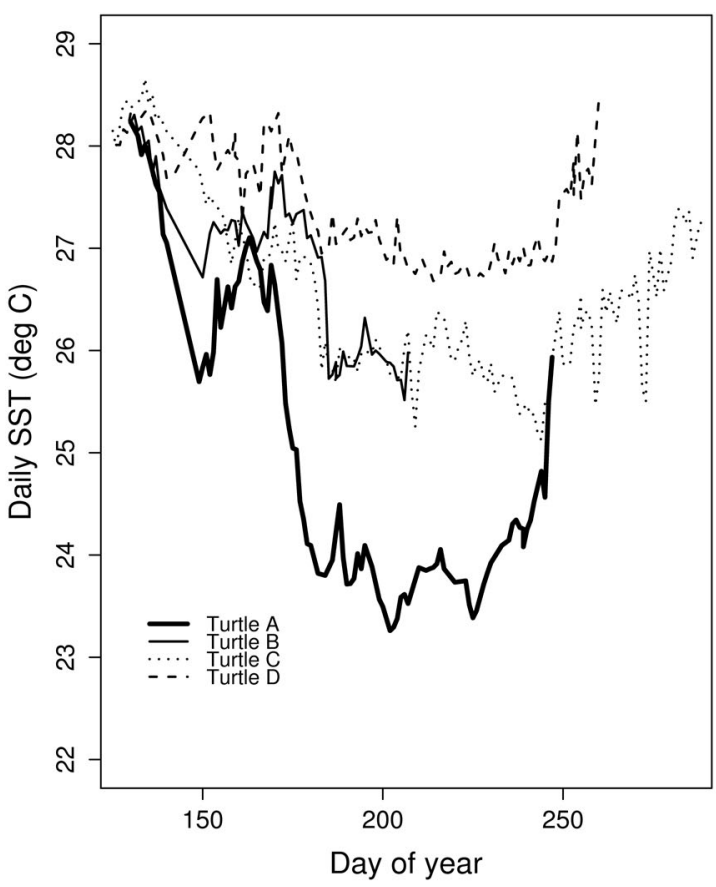

Fig. 9. Lepidochelys olivacea. Left panel = median ( $\pm 95 \%$ confidence limits) sea surface temperature (SST) for Turtles A-D for the duration of their satellite-relayed data logger (SRDL) record. Right panel = daily SST for Turtles A-D over their SRDL record (SRDLs typically record 1 temperature upcast each day)

within the water column and an emphasis on benthic diving. Although we had no direct data on the diet composition of the turtles from the population sampled, this generalist behaviour and benthic bias is consistent with previous descriptions of olive ridley turtles elsewhere having a generalist diet (Bjorndal 1997) and variable foraging behaviour (Polovina et al. 2003, Polovina et al. 2004). Of particular interest was the high proportion of dives that attained the bottom of the Arafura and Timor Seas and the evidence for a predominately benthic existence. The lack of a clear diel signal in the mean dive depths suggests that these benthic dives were not associated solely with resting or anti-predator behaviour (Fig. 7). As such, if these benthic dives comprise foraging activity, our results support previous inference about the behaviour and diet of olive ridley turtles which have shown frequent benthic activity (Polovina et al. 2003, Polovina et al. 2004) occurring often at great depths (Landis 1965). The hypothesised generalist mode of foraging is also congruent with the few studies and reports describing the diversified diet of this marine turtle species (e.g. salps, jellyfish, molluscs, crustaceans, bryozoans, fish eggs, sipunculids, ascidians, pelecypods, gastropods and algae) sampled elsewhere (reviewed in Bjorndal 1997).

However, distinguishing the true function of such benthic dives in marine turtles from profiles alone is not straightforward. Previously, resting dives made by marine turtles equipped with time-depth recorders
(TDRs) have been inferred by bouts of consistently Ushaped dives (mostly at night), with little or no variation in depth of the bottom phase consistent with a stationary animal (van Dam \& Diez 1996, Hays et al. 2004c). In contrast, non-resting dives (e.g. foraging) have been inferred from profiles with far more variation in the bottom phase (van Dam \& Diez 1996). In neritic hawksbill and green turtles, a strong nocturnal component to benthic resting has also been noted (van Dam \& Diez 1996, Hays et al. 2000), whereas pelagically feeding leatherback turtles often demonstrate a nocturnal foraging pattern corresponding to the vertical migrations of plankton that are closer to the surface at night (Hays et al. 2004a). Hence, nocturnal vs. diurnal patterns of activity seem to vary across species. We can say with confidence that 3 of the 4 individuals we tracked made deep benthic dives, and the depth and prevalence of these dives is certainly unusual for hard-shelled turtles. However, distinguishing the function of these dives is complicated because there were few sequences of long-form dives with which to test for the existence of regular bouts of U-shaped dives. Certainly in shallow-diving species (e.g. hawksbill, green and loggerhead turtles), when individuals dive to the seabed, some dives typically serve a resting function while others are associated with foraging. It is therefore logical to expect that the benthic dives we recorded might have served these 2 functions. 
Our data also revealed some interesting and unexpected traits of this species that have not been documented previously. Most turtles performed extraordinary long dives (nearly 10\% lasted longer than $1 \mathrm{~h})$, with the maximum dive lasting $3.33 \pm 0.33 \mathrm{~h}$, although others have noted relatively long dive durations for this species (Plotkin cited in Lutcavage \& Lutz 1997). This is particularly remarkable considering the thermal environment in which these turtles live. Most turtles encountered SSTs within the range of 23 to $29^{\circ} \mathrm{C}$, with few of the deep ( $\geq 100 \mathrm{~m}$ ) dives measuring temperatures $<20^{\circ} \mathrm{C}$ at maximum depth. Previous studies of loggerhead turtle dive durations during winter conditions have measured dives of $7 \mathrm{~h}$ when SSTs were consistently $<15^{\circ} \mathrm{C}$, suggesting that extended diving times result from temperature-mediated reductions in diving metabolic rate associated with hibernation (Hochscheid et al. 2005). Although we did observe diel patterns in dive duration, i.e. longer durations during the early morning (Fig. 7), it is doubtful that any substantial variation in oceanic water temperatures occurred during this time. Further, the long dive durations observed for the shallower-diving Turtle A could not be explained by observations of low water temperatures at depth. Another possibility is that turtles were resting during the early hours of the morning and thus had lower metabolic rates, although the lack of a diel signal in dive depth suggests that any resting behaviour occurred at many different depths and times.

It is conceivable that the long dives we recorded were not a consequence of cold waters, but of anaerobic respiration during part of the dive. We can examine this possibility by considering the pattern of diving and surfacing. The relative length of dives and post-dive surface intervals is frequently used as an indication of whether animals are diving aerobically or anaerobically (Costa et al. 2001). Across a range of diving birds, mammals and reptiles, the prevailing view is that dives are mainly aerobic (e.g. Hays et al. 2000, Hindell et al. 2000, Croll et al. 2001), although there are exceptions (e.g. Kooyman et al. 1980, Costa et al. 2001). This is the best strategy for maximising the amount of the time that can be spent diving, because relatively little time is spent recovering at the surface between dives (Mori 1998, 1999, Thompson \& Fedak 2001). The fact that dives by the instrumented olive ridleys were relatively long compared to their surface intervals suggests that in common with many other diving species, olive ridleys were diving aerobically. Even though we detected a positive relationship between the post-dive surface interval and dive duration for 2 turtles, longer surface intervals following long, aerobic dives are expected given the requirement of recharging oxygen stores. It is therefore plausible to hypothesise that this species of hard-shelled marine turtle is capable of achieving either unexpectedly low diving metabolic rates or storing high concentrations of oxygen allowing it to exploit the benthic environment of shallow tropical seas. Indeed, the occasional manifestation of extremely long dives well beyond the median suggests that during these dives, olive ridleys approach or even go beyond their aerobic dive capacity. However, the competing hypotheses of low metabolic rates and high oxygen storage capacity still need to be tested using respirometry and direct measurements of oxygen stores in a laboratory setting (e.g. Lapennas \& Lutz 1982, Southwood et al. 2003).

In general terms, olive ridley turtles seem to be able to occupy a different niche to other species of turtle (Polovina et al. 2003, Polovina et al. 2004). While the juveniles of several species live in an oceanic environment, possibly feeding on plankton and neuston (Bjorndal 1997), most hard-shelled species (e.g. green turtles, hawksbill turtles) spend their adult lives in shallow coastal environments (Lutz \& Musick 1996, Seminoff et al. 2003, Lopez-Mendilaharsu et al. 2005). In contrast, adult leatherback turtles move extensively across ocean basins and dive deeply in the oceanic zone to feed on gelatinous plankton (Ferraroli et al. 2004, Hays et al. 2004b). We showed clearly that olive ridley turtles diverge from these general paradigms in foraging turtles by spending long periods diving towards the seabed far from land in relatively deep water. This deep benthic activity seems unusual for sea turtles, but does occur in some diving mammals and birds. For example, grey seals Halichoerus grypus are largely benthic foragers (Thompson et al. 1991), and narwhals Monodon monoceros can forage on the seabed at depths of at least $800 \mathrm{~m}$ where they target deep-water fish and squid species (Laidre et al. 2003). Similarly, while penguins generally feed pelagically, it has been shown that in some situations certain species may dive deeply to feed near the seabed (Tremblay \& Cherel 2000).

Our success to date in obtaining some of the highest quantity and quality of data for a hard-shelled turtle fitted with a satellite tag (cf. Plotkin et al. 1996, Plotkin 1998, M. Fedak pers. comm.) was perhaps due the application of a small wedge to improve communication between the unit and the Argos satellite network. This modification made the antenna point perpendicularly to the water surface when the animal breached. It is also possible that this species demonstrates a relative high surfacing rate that may facilitate communications with the Argos network, although previous work on the same species elsewhere has had lower success in data retrieval (Plotkin 1998, Plotkin et al. 1996).

Our results also have important implications for the management of this species in northern Australia and Southeast Asia. The extensive movements (>1000 km) 
measured from 4 tags and the variability in migration pathways suggest that this population is potentially susceptible to a wide range of human activities in the general region. The management of turtle egg harvest by Australian Aboriginal groups (Kennett et al. 2004) should therefore take into consideration the broader activities of clans across the entire range of the northern Australian coastline; and those responsible for turtle conservation in Australia must consider it likely that olive ridleys nesting in Australia are susceptible to threats in the oceanic region such as fishing by-catch (Poiner et al. 1990, Poiner \& Harris 1996, Tucker et al. 1997, Salini et al. 2000) and direct predation by artisanal fisherman (Nuitja \& Lazell Jr 1982, Limpus 1997, Meylan \& Donnelly 1999) throughout Papua New Guinea, Indonesia and Timor-Leste.

Acknowledgements. We thank the Gumurr-Marthakal Rangers: M. Atu, D. Garambaka, J. Gurrumgurrum, B. Lirrwa Ganambar, J. Nhumeya Yunupingu, D. Wunungmurra for assistance and direction in the field; the Traditional Owners of the region: B. Rrayini, J. Manyguluma, H. Dawity, S. Mukawatpy, J. Daymangu, C. Guthadjaka for access to traditional land and sea country; T. Mahney of the Northern Land Council; O. Datdjarranga and J. Rangata of the Marthakal Homeland and Resource Centre Association; C. Baker, M. Huddleston, P. Huddleston, R. Huddleston, S. Muller, D. Loechel, J. Scahrf, D. Scahrf, M. Meekan, S. Fitch, K. Dethmers and the residents of Gawa Outstation, Elcho Island. Logistics and supplies provided by Charles Darwin University, School for Environmental Research. Funding was provided by a Natural Environment Research Council (UK) grant to G.C.H. and an Australian Academy of Science Visiting Fellowship to C.J.A.B. We thank D. Pinaud (CNRS) for providing the $R$ code to interpolate daily locations and 3 anonymous reviewers for helpful comments to improve the manuscript. All authors collected the data, designed the study, did the analysis and wrote the paper.

\section{LITERATURE CITED}

Akaike H (1973) Information theory as an extension of the maximum likelihood principle. In: Petrov BN, Csaki F (eds) Proceedings of the Second International Symposium on Information Theory. Budapest, p 267-281

Bellwood DR, Wainwright PC, Fulton CJ, Hoey AS (2006) Functional versatility supports coral reef biodiversity. Proc R Soc Biol Sci Ser B 273:101-107

Bjorndal KA (1997) Foraging ecology and nutrition of sea turtles. In: Lutz PJ, Musick JA (eds) The biology of sea turtles. CRC Press, Boca Raton, FL, p 199-231

Bradshaw AD (1965) Evolutionary significance of phenotypic plasticity in plants. Adv Genet 13:115-155

Bradshaw CJA, Hindell MA, Michael KJ, Sumner M (2002) The optimal spatial scale for the analysis of elephant seal foraging as determined by geo-location in relation to sea surface temperatures. ICES J Mar Sci 59:770-781

Burke VJ, Morreale SJ, Standora EA (1994) Diet of the Kemp's ridley sea turtle, Lepidochelys kempii, in New York waters. Fish Bull 92:26-32

Burnham KP, Anderson DR (2002) Model selection and multimodal inference: a practical information-theoretic approach. Springer-Verlag, New York

Costa DP, Gales NJ, Goebel ME (2001) Aerobic dive limit: How often does it occur in nature? Comp Biochem Physiol A 129:771-783

Croll DA, Acevedo-Gutierrez A, Tershy BR, Urban-Ramirez J (2001) The diving behavior of blue and fin whales: Is dive duration shorter than expected based on oxygen stores? Comp Biochem Physiol A 129:797-809

Ellis JR, Pawson MG, Shackley SE (1996) The comparative feeding ecology of six species of shark and four species of ray (elasmobranchii) in the north-east Atlantic. J Mar Biol Assoc UK 76:89-106

Fedak MA, Lovell P, Grant SM (2001) Two approaches to compressing and interpreting time-depth information as collected by time-depth recorders and satellite-linked data recorders. Mar Mamm Sci 17:94-110

Fedak MA, Lovell P, McConnell BJ, Hunter C (2002) Overcoming the constraints of long range radio telemetry from animals: getting more useful data from smaller packages. Integr Comp Biol 42:3-10

Ferraroli S, Georges JY, Gaspar P, Le Maho Y (2004) Endangered species: where leatherback turtles meet fisheries. Nature 429:521-522

Gabriel W, Luttbeg B, Sih A, Tollrian R (2005) Environmental tolerance, heterogeneity, and the evolution of reversible plastic responses. Am Nat 166:339-353

Garrison LP, Link JS (2000) Dietary guild structure of the fish community in the Northeast United States continental shelf ecosystem. Mar Ecol Prog Ser 202:231-240

Godley BJ, Smith SM, Clark PF, Taylor JD (1997) Molluscan and crustacean items in the diet of the loggerhead turtle, Caretta caretta (Linnaeus, 1758) Testudines: chelonidae in the eastern Mediterranean. J Molluscan Stud 63:474-476

Harcourt RG, Bradshaw CJA, Dickson K, Davis LS (2002) Foraging ecology of a generalist predator, the female New Zealand fur seal. Mar Ecol Prog Ser 227:11-24

Hays GC, Adams CR, Broderick AC, Godley BJ, Lucas DJ, Metcalfe JD, Prior AA (2000) The diving behaviour of green turtles at Ascension Island. Anim Behav 59:577-586

Hays GC, Åkesson S, Godley BJ, Luschi P, Santidrian P (2001) The implications of location accuracy for the interpretation of satellite-tracking data. Anim Behav 61:1035-1040

Hays GC, Houghton JDR, Isaacs C, King RS, Lloyd C, Lovell P (2004a) First records of oceanic dive profiles for leatherback turtles, Dermochelys coriacea, indicate behavioural plasticity associated with long-distance migration. Anim Behav 67:733-743

Hays GC, Houghton JDR, Myers EH (2004b) Endangered species: pan-Atlantic leatherback turtle movements. Nature 429:522

Hays GC, Metcalfe JD, Walne AW (2004c) The implications of lung-regulated buoyancy control for dive depth and duration. Ecology 85:1137-1145

Hindell MA, Lea MA, Morrice MG, McMahon CR (2000) Metabolic limits on dive duration and swimming speed in the southern elephant seal Mirounga leonina. Physiol Biochem Zool 73:790-798

Hochscheid S, Bentivegna F, Hays GC (2005) First records of dive durations for a hibernating sea turtle. Biol Lett 1:82-86

Holland DL, Davenport J, East J (1990) The fatty acid composition of the leatherback turtle Dermochelys coriacea and its jellyfish prey. J Mar Biol Assoc UK 70:761-770

IOC/IHO/BODC (2003) Centenary edition of the GEBCO digital atlas. Published on CD-ROM on behalf of the Intergovernmental Oceanographic Commission and the International Hydrographic Organization as part of the General 
Bathymetric Chart of the Oceans, British Oceanographic Data Centre, Liverpool

Kennett R, Robinson CJ, Kiessling I, Yunupingu D, Munungurritj N, Yunupingu D (2004) Indigenous initiatives for co-management of miyapunu/sea turtle. Ecol Manag Restor 5:159-166

Kooyman GL, Wahrenbrock EA, Castellini MA, Davis RW, Sinnett EE (1980) Aerobic and anaerobic metabolism during voluntary diving in Weddell seals: evidence of preferred pathways from blood chemistry and behavior. J Comp Physiol B 138:335-346

Kotze DJ, O'Hara RB (2003) Species decline-but why? Explanations of carabid beetle (Coleoptera, Carabidae) declines in Europe. Oecologia 135:138-148

Laidre KL, Heide-Jørgensen MP, Dietz R, Hobbs RC, Jørgensen OA (2003) Deep-diving by narwhals Monodon monoceros: differences in foraging behavior between wintering areas? Mar Ecol Prog Ser 261:269-281

Landis CJ (1965) Research: new high pressure research animal? Undersea Technol 6:21

Lapennas GN, Lutz PL (1982) Oxygen affinity of sea turtle blood. Respir Physiol 48:59-74

Leon YM, Bjorndal KA (2002) Selective feeding in the hawksbill turtle, an important predator in coral reef ecosystems. Mar Ecol Prog Ser 245:249-258

Limpus CJ (1997) Marine turtle populations of Southeast Asia and the Western Pacific region: distribution and status. In: Noor YR, Lubis IR, Ounsted R, Troeng S, Abdullah H (eds) Marine turtle research and management in Indonesia. Wetlands International/PH/PA/Environment Australia, Bogor, p $37-72$

Lopez-Mendilaharsu M, Gardner SC, Seminoff JA, Riosmena-Rodriguez R (2005) Identifying critical foraging habitats of the green turtle (Chelonia mydas) along the Pacific coast of the Baja California peninsula, Mexico. Aquat Conserv Mar Freshw Ecosyst 15:259-269

Luschi P, Hays GC, Papi F (2003) A review of long-distance movements by marine turtles, and the possible role of ocean currents. Oikos 103:293-302

Lutcavage ME, Lutz PL (1997) Diving physiology. In: Lutz PL, Musick JA (eds) The biology of sea turtles, Vol 1. CRC Press, Boca Raton, Florida, p 277-296

Lutz PL, Musick JA (eds) (1996) The biology of sea turtles. CRC Press, Boca Raton, FL

McKinney ML (1997) Extinction vulnerability and selectivity: combining ecological and paleontological views. Annu Rev Ecol Syst 28:495-516

McMahon CR, Autret E, Houghton JD, Lovell P, Myers AE, Hays GC (2005) Animal borne sensors successfully capture the thermal properties of ocean basins. Limnol Oceanogr Methods 3:392-398

Meylan A (1988) Spongivory in hawksbill turtles - a diet of glass. Science 239:393-395

Meylan AB, Donnelly M (1999) Status justification for listing the hawksbill turtle (Eretmochelys imbricata) as Critically Endangered on the 1996 IUCN Red List of Threatened Animals. Chelonian Conserv Biol 3:200-224

Mori Y (1998) The optimal patch use in divers: optimal time budget and the number of dive cycles during bout. J Theor Biol 190:187-199

Mori Y (1999) The optimal allocation of time and respiratory metabolism over the dive cycle. Behav Ecol 10:155-160

Myers AE, Lovell P, Hays GC (2006) Tools for studying animal behaviour: validation of dive profiles relayed via the Argos satellite system. Anim Behav 71:989-993

Nuitja INS, Lazell JD Jr (1982) Marine turtle nesting in Indonesia. Copeia 1982:708-710
Pimm SL (1991) The balance of nature? Ecological issues in the conservation of species and communities. University of Chicago Press, Chicago, IL

Pinaud D, Weimerskirch H (2005) Scale-dependent habitat use in a long-ranging central place predator. J Anim Ecol 74:852-863

Pinheiro JC, Bates DM (2000) Mixed-effects models in S and S-Plus (Statistics and computing). Springer-Verlag, New York

Plotkin PT (1998) Interaction between behavior of marine organisms and the performance of satellite transmitters: a marine turtle case study. Mar Technol Soc J 32:5-10

Plotkin P (2003) Adult migrations and habitat use. In: Lutz PL, Musick JA (eds) The biology of sea turtles, Vol 2. CRC Press, Boca Raton, FL, p 225-241

Plotkin PT, Wicksten MK, Amos AF (1993) Feeding ecology of the loggerhead sea turtle Caretta caretta in the Northwestern Gulf of Mexico. Mar Biol 115:1-5

Plotkin PT, Byles RA, Rostal DC, Owens DW (1995) Independent versus socially facilitated oceanic migrations of the olive ridley, Lepidochelys olivacea. Mar Biol 122:137-143

Plotkin PT, Owens DW, Byles RA, Patterson R (1996) Departure of male olive ridley turtles (Lepidochelys olivacea) from a nearshore breeding ground. Herpetologica 52:1-7

Poiner IR, Buckworth RC, Harris ANM (1990) Incidental capture and mortality of sea turtles in Australia's northern prawn fishery. Aust J Mar Freshw Res 41:97-110

Poiner IR, Harris ANM (1996) Incidental capture, direct mortality and delayed mortality of sea turtles in Australia's northern prawn fishery. Mar Biol 125:813-825

Polovina JJ, Howell E, Parker DM, Balazs GH (2003) Divedepth distribution of loggerhead (Carretta carretta) and olive ridley (Lepidochelys olivacea) sea turtles in the central North Pacific: Might deep longline sets catch fewer turtles? Fish Bull 101:189-193

Polovina JJ, Balazs GH, Howell EA, Parker DM, Seki MP, Dutton PH (2004) Forage and migration habitat of loggerhead (Caretta caretta) and olive ridley (Lepidochelys olivacea) sea turtles in the central North Pacific Ocean. Fish Oceanogr 13:36-51

R Development Core Team (2004) R: A language and environment for statistical computing. R Foundation for Statistical Computing, Vienna

Royal Admirality (2003) 1:3,500,000 Nautical chart of Australia, North Coast and adjacent waters. United Kingdom Hydrographic Office, Taunton

Salini J, Brewer D, Farmer M, Rawlinson N (2000) Assessment and benefits of damage reduction in prawns due to use of different bycatch reduction devices in the Gulf of Carpentaria, Australia. Fish Res 45:1-8

Salmon M, Jones TT, Horch KW (2004) Ontogeny of diving and feeding behavior in juvenile seaturtles: leatherback seaturtles (Dermochelys coriacea L) and green seaturtles (Chelonia mydas L) in the Florida current. J Herpetol 38: 36-43

Seaborn GT, Moore MK, Balazs GH (2005) Depot fatty acid composition in immature green turtles (Chelonia mydas) residing at two near-shore foraging areas in the Hawaiian Islands. Comp Biochem Physiol B 140:183-195

Seminoff JA, Jones TT, Resendiz A, Nichols WJ, Chaloupka MY (2003) Monitoring green turtles (Chelonia mydas) at a coastal foraging area in Baja California, Mexico: multiple indices to describe population status. J Mar Biol Assoc UK 83:1355-1362

Seney EE, Musick JA (2005) Diet analysis of Kemp's ridley sea turtles (Lepidochelys kempii) in Virginia. Chelonian Conserv Biol 4:864-871 
Shanker K, Pandav B, Choudhury BC (2004) An assessment of the olive ridley turtle (Lepidochelys olivacea) nesting population in Orissa, India. Biol Conserv 115:149-160

Southwood AL, Darveau CA, Jones DR (2003) Metabolic and cardiovascular adjustments of juvenile green turtles to seasonal changes in temperature and photoperiod. J Exp Biol 206:4521-4531

Takahashi A, Dunn MJ, Trathan PN, Sato K, Naito Y, Croxall JP (2003) Foraging strategies of chinstrap penguins at Signy Island, Antarctica: importance of benthic feeding on Antarctic krill. Mar Ecol Prog Ser 250:279-289

Thompson D, Fedak MA (2001) How long should a dive last? A simple model of foraging decisions by breath-hold divers in a patchy environment. Anim Behav 61:287-296

Thompson D, Hammond PS, Nicholas KS, Fedak MA (1991) Movements, diving and foraging behaviour of grey seals (Halichoerus grypus). J Zool 224:223-232

Thompson PM, Tollit DJ, Corpe HM, Reid RJ, Ross HM (1997) Changes in haematological parameters in relation to prey switching in a wild population of harbour seals. Funct Ecol

Editorial responsibility: Rory Wilson (Contributing Editor), Swansea, Wales, UK
$11: 743-750$

Tollrian R, Harvell CD (eds) (1999) The ecology and evolution of inducible defenses. Princeton University Press, Princeton, NJ

Tomas J, Aznar FJ, Raga JA (2001) Feeding ecology of the loggerhead turtle Caretta caretta in the western Mediterranean. J Zool 255:525-532

Tremblay Y, Cherel Y (2000) Benthic and pelagic dives: a new foraging behaviour in rockhopper penguins. Mar Ecol Prog Ser 204:257-267

Tucker AD, Robins JB, McPhee DP (1997) Adopting turtle excluder devices in Australia and the United States: What are the differences in technology transfer, promotion, and acceptance? Coast Manag 25:405-421

van Dam RP, Diez CE (1996) Diving behavior of immature hawksbills (Eretmochelys imbricata) in a Caribbean cliffwall habitat. Mar Biol 127:171-178

Votier SC, Furness RW, Bearhop S, Crane JE and 11 others (2004) Changes in fisheries discard rates and seabird communities. Nature 427:727-730

Submitted: March 3, 2006; Accepted: June 6, 2006 Proofs received from author(s): December 11, 2006 